Article

\title{
Towards Sustainable Project Management: Evaluation of Relationship-Specific Risks and Risk Determinants Threatening to Achieve the Intended Benefit of Interorganizational Cooperation in Engineering Projects
}

\author{
Maria Krechowicz $\mathbb{C}$
}

check for

updates

Citation: Krechowicz, M. Towards Sustainable Project Management: Evaluation of Relationship-Specific Risks and Risk Determinants Threatening to Achieve the Intended Benefit of Interorganizational

Cooperation in Engineering Projects. Sustainability 2022, 14, 2961. https:// doi.org/10.3390/su14052961

Academic Editors: Isabel Ortiz-

Marcos and Rocío Rodríguez-Rivero

Received: 25 January 2022

Accepted: 1 March 2022

Published: 3 March 2022

Publisher's Note: MDPI stays neutral with regard to jurisdictional claims in published maps and institutional affiliations.

Copyright: (C) 2022 by the author. Licensee MDPI, Basel, Switzerland. This article is an open access article distributed under the terms and conditions of the Creative Commons Attribution (CC BY) license (https:// creativecommons.org/licenses/by/ $4.0 /)$.
Faculty of Management and Computer Modelling, Kielce University of Technology, 25-314 Kielce, Poland; mkrechowicz@tu.kielce.pl

\begin{abstract}
Nowadays, we can observe a growing number of investment projects in the construction industry and environmental engineering, as well as a growing interest in socially responsible projects aiming to contribute to sustainable development. Interorganizational cooperation in engineering projects is associated with many opportunities and risks that continue to be a challenge for today's world. The aim of this work is to identify and assess relationship-specific risks and risk determinants threatening to achieve the intended benefit of interorganizational cooperation and to develop assumptions for the risk management model in such projects. It will support sustainable project management in interorganizational engineering projects and increase their sustainability. In this work, 18 risks and 28 risk determinants were identified. Risks' frequency of occurrence, consequences, possibility of detection and Risk Priority Numbers as well as the significance of risk determinants were assessed based on the data gathered from 12,352 interorganizational projects from 100 Polish companies. It was found that self-interest orientation, hiding internal problems and/or problems related to the joint venture, unfavourable and imprecise contract, and lack of a good project coordinator pose the highest risk in interorganizational engineering projects. The study revealed that the highest Risk Priority Numbers in interorganizational projects were generally obtained for construction projects, lower for socially responsible projects taken by engineering companies, and the lowest for environmental engineering projects.
\end{abstract}

Keywords: risk assessment; sustainable project management; interorganizational relationships; interorganizational cooperation; FMEA

\section{Introduction}

Nowadays, organizations are eager to develop new products and services to attract customers, offer competitive prices, as well as meet the increasing demands of their clients. These requirements impose the necessity of interorganizational cooperation and the execution of interorganizational projects to use the diverse professional knowledge, experience, skills and resources of various organizations [1,2]. The cooperation of several business entities also facilitates the transfer of experience and knowledge, as well as other resources, e.g., material or financial. It enables the diffusion of knowledge, as well as technical solutions used in individual cooperating enterprises, which may constitute a solid basis for the joint creation of innovation [3]. It is especially visible in the case of the growing number of investment projects taken in the construction and environmental engineering sectors, as well as socially responsible initiatives taken by many parties.

The sustainability of a project has an impact on the way a project is planned, designed, executed, managed, and governed [4]. It is the basis for Sustainable Project Management (SPM), which combines considering environmental, economic, and social features of the 
project's lifecycle with the project's planning, monitoring, and controlling processes, intended to gain benefits for stakeholders, and carried out in a fair, transparent and ethical way, including the proactive participation of stakeholders [5]. SPM requires considering a project and management by taking into account a wider time horizon, a wide range of perspectives and a wide set of stakeholders [6]. The concept of sustainability and SPM is used in project management and project delivery, e.g., the procurement process [7], project monitoring [8], risk identification and risk management [9], to reduce the risk of cost inaccuracy in infrastructure projects [10], in risk management in development projects [11], and in stakeholder's identification and engagement [8,12]. The relationship-specific risk assessment of interorganizational projects covers various aspects of sustainability: economic sustainability and social and administrative sustainability. Economic sustainability is focused on fitting the project into the company's strategy and assessing its contribution on long-term viability. Social and administrative sustainability covers issues connected with an organization's culture, structure, as well as human resource practices and skills.

When analysing the issues of inter-organizational cooperation, one cannot omit the concept of the quality of inter-organizational relations. The definition of Relationship Quality (RQ) has evolved over time, taking on more and more new dimensions. Initially, the concept of relationship quality was proposed as an indicator of the extent to which a given relationship is appropriate to achieve specific goals. Hennig-Thurau and Klee in 1997 defined the quality of relations as "the degree of adjustment of the relationship to meet the final needs of the investor" [13]. Currently, it is commonly believed that the quality of relations is a concept composed of several different, although interrelated, dimensions or attributes, which can serve as a tool for assessing the status of relations between organizations [14]. The following were considered attributes or dimensions of the quality of a relationship: ethical behaviour, satisfaction, commitment, opportunism, and trust [15].

Although the topic of the quality of interorganizational relationship and problems occurring in inter-organizational projects has already been discussed in the literature, the subject of relationship-specific risks threatening to achieve the intended benefit of interorganizational cooperation has not been described in the literature so far. Bearing in mind the identified research gap, the aim of the work is to identify and assess relationship-specific risks and risk determinants that threaten to achieve the intended benefit of interorganizational cooperation and to develop assumptions for the risk management model in such projects. It is expected that it will enable in the future the development of a theoretical model of risk management of the occurrence of unfavourable relations in interorganizational projects.

For the purposes of the study, the following research questions were formulated:

RQ1: Which relationship-specific risk threatening to achieve the intended benefit of interorganizational cooperation:

(a) Is the most frequent in interorganizational projects taken by engineering companies?

(b) Has the greatest consequences?

(c) Has the lowest detection possibilities?

RQ2: Which relationship-specific risks threatening to achieve the intended benefit of interorganizational cooperation had the highest Risk Priority Number in engineering interorganizational projects in general (AAP) and in three specified groups: interorganizational building construction projects $(\mathrm{BCP})$, interorganizational projects in environmental engineering (IEEP)and interorganizational socially responsible projects (ISRP)?

RQ3: Which relationship-specific risk determinants for failure to achieve the intended benefit of interorganizational cooperation were the most important in interorganizational engineering projects in general (AAP), and in three specified groups (BCP, IEEP and ISRP)?

The outline of this paper is as follows. Section 2 presents a review of the literature. Section 3 describes the proposed approach, including data gathering and research methodology. The results are presented in Section 4. Section 5 discusses the results, limitations of the proposed approach, and future research direction. Section 6 summarizes the paper. 


\section{Literature Review}

Nowadays, a growing number of investment projects in construction industry and environmental engineering can be observed, as well as a growing interest in socially responsible projects, aiming to contribute to sustainable development, namely, economic growth, social progress, and effective protection of the environment. That is why the author's attention was focused on these types of interorganizational projects.

\subsection{Specificity of Interorganizational Building Construction and Environmental Engineering Projects}

Nowadays, there is an increase in the number of investments in the field of housing, road, rail, and water construction worldwide. More and more investments are also carried out in the field of environmental engineering. This is due to the expansion of cities and the need to provide new housing estates with proper infrastructure and strive for sustainable development. The typical participants in construction or environmental engineering projects include clients, designers, contractors, and material manufacturers or suppliers. Their levels of involvement in the project vary at different stages in the process. This reflects the segmented nature of the construction and environmental engineering industry, which results from various specialties of cooperating companies towards project completion in distinct separate stages, as it is stated in a traditional procurement system [16]. The companies engaged in the project often have different perceptions of priorities which can result in misunderstandings, friction, and issues during project execution [17].

\subsection{Specificity of Interorganizational Corporate Responsibility Projects Taken by Engineering Companies}

Corporate Social Responsibility (CSR) has become a complex and interdisciplinary term [18] that has become a topic of growing interest in recent decades [19-21]. This term covers the active, voluntary dedication of enterprise resources to implement activities aiming to improve the quality of life in society [22], upgrade the quality of the environment, solve social problems [23] and contribute to sustainable economic development. In recent years, along with the growing interest in CSR from companies and increased social awareness of sustainable development, more and more companies have decided to carry out CSR projects [24]. The number of CSR projects has grown because they are not only a business opportunity, but also a picture of stakeholders' expectations, and therefore show a significant connection between business success, competitiveness, and sustainability [25].

Civil engineering companies and construction companies have a significant impact on the natural environment and citizens due to their massive consumption of natural resources, large production of waste and emitting pollutants [26] causing danger and accidents at the construction site $[27,28]$. That is why the topic of CSR is of particular relevance for civil engineering companies and building construction companies, who aim to compensate for their negative impact on the environment and try to meet the expectations of environmental and socially conscious clients [29-31]. Duman, Giritliand McDermott [32] found that construction companies are aware of the growing importance of CSR. Nevertheless, the scale of company's activity and the country's specificity characteristics greatly influence CSR preferences. In [31], the motives, barriers, and effects of taking CSR principles by enterprises of the Polish construction sector were studied. Kowalczyk [33] found out that stakeholder pressure is the most important factor influencing CSR-culture and CSR-practice of construction companies in Europe.

A certain part of CSR projects is interorganizational projects, requiring the cooperation of several entities. There are many reasons that motivate the entity to establish cooperation to undertake socially responsible initiatives-one of them is the willingness to respond to specific social problems. These issues include social exclusion, security, malnutrition, food waste, increased waste, use of water, and other resources. Solving such problems is a multistage process that requires extensive competences and resources, which are often not concentrated in one institution or enterprise, but can extend to various sectors: 
private, social (especially non-governmental organizations) and public. The willingness to undertake social responsibility activities and to meet the needs reported by stakeholders mobilize all sectors and undertake various types of activities, both independently and in interorganizational cooperation [3]. Some enterprises are more willing to engage in socially responsible initiatives in cooperation with the third sector to gain experience in this matter [34] and increase the chances of receiving social acceptance for their activities.

\subsection{Problems with Interorganizational Projects Taken by Engineering Companies}

Challenges of interorganizational projects, such as: fluid team boundaries, temporary membership, and cross-functionalities, may cause difficulties in project execution, unless properly addressed $[1,2,35]$. It also happens that the cooperation can be threatened by the entanglement of practices in the interorganizational environment, and uncertainty due to missing shared context between the cooperating parties. The problem can be compounded by a lack of cooperation history between the organizations and the interpersonal differences resulting from it [36]. One party feeling that they have a key role in the project can create tension between the parties involved, leading to unfavourable interorganizational relationships. To prevent such situations, relational contracting methods were introduced in investment projects to cure the negative effects that may result from the interaction of various parties involved in the project [16]. Both in interorganizational investment projects and in interorganizational socially responsible initiatives, there occur unfavourable opportunistic relations and behaviours, therefore, there is now a move towards a relationshipbased approach to procurement and a working environment based on mutual trust [37,38]. Furthermore, tensions in interorganizational projects can be prevented using informal mechanisms for governance (governmentalities) [39]. Moreover, historically, there can be observed a movement towards good quality relationships and collaboration development aiming to develop stronger and more constructive bonds for better troubleshooting and problem solving. Ultimately, this is to improve project performance and outcomes in a more business-oriented environment with a clear, long-term goal [40]. Inter-organizational relations are a vital element of today's economic and social reality. This issue is the subject of intensive research in the literature because it is an important management tool in contemporary organizations [41]. Thanks to properly formed relationships, enterprises can strengthen their position on the market, better use their potential, and achieve better results from implemented projects.

In [42], four groups of barriers in introducing collaborative interorganizational relationships in the construction industry were presented. Cultural barriers included: concentration on tasks while overlooking interactions between people [43], absence of social bonding [44], unwanted prioritization of relationships [45], inflexible adjustment to changes [46], and uncertainty [43]. Organizational barriers covered: different objectives [47], various inconsistent interpretations of the problem [43], absence of customer participation [43], and disproportion between contribution and dependency [48]. Industry-related barriers included: high technical complexity [49], unified contracts [50], bureaucracy [51], and interdependencies [52]. Barriers connected with resources covered: financial security [51], resources' availability [51], partnering process' risk liability [53], and high time and resource consumption of the partnering process [47]. In [54], a risk analysis method for inter-organizational business models was presented, in which risk is considered as the probability of the value transfer not succeeding, multiplied by the missing value.

The traditional method of project delivery is design-bid-build (DBB). According to this method, the owner contracts with separate entities for the project's design and construction [55]. It is a sequential process and may lead to unfavourable relations between the ordering party (owner), the designer, and the contractor. Often, the reason for the occurrence of unfavourable relations is the lack of communication and integration of the participants of the investment process. That is why the Alternative Project Delivery Methods (APDM) concept was introduced to improve the integration of the parties involved in the investment process, increase the economic efficiency of the investment, and reduce 
the risk. Currently, during the realization of investment projects in many countries, it can be observed that more and more emphasis is put on the use of interorganizational relationship management. APDMS, such as the construction manager at risk (CMAR) and the design and build (DB) system are becoming more and more popular [56]. Another procurement method is partnering, which is intended to encourage parties to work together towards shared objectives in an environment of trust and openness [57] and therefore contributes to the elimination of adverse relationships between owners and contractors [58,59]. Partnering aims to develop close relationships among the entities in a project [60]. The higher the level of commitment to shared goals, the more successful the partnering [61].

Although the traditional procurement methods are gradually being abandoned, and project implementation systems based on the development of favourable relations between the participants of the investment process are increasingly used [62], practice shows that many problems are still reported during project execution caused by unfavourable interorganizational relationships. Increasing complexity of the projects and a large number of new technologies used in building construction, and environmental engineering industries require the effective cooperation of many entities and prompts a deep analysis of the relationship between the entities engaged in the project.

Relationship management enables the provision of appropriate cooperation environments and defines the framework for all participants in the investment process to adapt their behaviour to the objectives of the project and appropriate involvement in the work. Research conducted by I.R. MacNeil) [63] shows that the approach aimed at developing beneficial relations between participants of the investment process, such as cooperation, ensures a positive contribution to sustainable social, environmental and economic development and helps to satisfy the interests of all parties involved in the implementation of the investment project. X. Meng, M. Sun, and M. Jones [64] proposed a hierarchical division of relations between the participants of the investment process into four levels of maturity (focus on price, focus on quality, focus on partnership relations and focus on strategic partnership). In [40], several relational attributes were given, including teamwork, commitment, trust, and performance satisfaction; seven strategies for achieving these attributes were also presented.

In [65-67], it was proved that effective technical risk management in engineering projects concerning buildings with renewable energy sources, low-energy buildings with innovative renewable energy sources and sustainable trenchless pipelaying supports achieving the project's goal with higher probability. However, relationship-based risks have not been considered so far in the risk management model in such projects.

Nevertheless, in the literature, no studies related to the risks and mechanisms determining the occurrence of unfavourable interorganizational relations threatening to achieve the goal of investment projects in the construction and environmental engineering industries have been found.

CSR initiatives should be associated not only with benefits, but also with risks. Risks connected with taking CSR initiatives are presented in [68]. However, those risks do not include relation-specific risks. Moreover, CSR projects undertaken in cooperation with other entities are prone to the emergence of unfavourable interorganizational relations, which can jeopardize the achievement of the project objectives. If entities cooperating with each other are not aware of the need to manage risk and do not take any actions to monitor risk occurrence, it is difficult to achieve maximum efficiency. In the literature, no studies related to the risks and mechanisms determining the occurrence of unfavourable interorganizational relations threatening to achieve the goal of interorganizational socially responsible initiatives have been found.

To sum up, the literature research revealed a number of problems in interorganizational projects, such as fluid team boundaries, temporary membership and crossfunctionalities $[1,2,35]$, missing shared context between the cooperating parties, a lack of cooperation history between the organizations, one party feeling that they have a key role in the project [36], lack of communication and integration of the participants [56], 
different perceptions of priorities which can result in misunderstandings of the parties involved [17]. Moreover, it revealed several barriers in collaborative interorganizational relationships in the construction industry. Although they reflect the multiplicity of possible problems in inter-organizational collaboration in construction companies, they do not exhaust the complete list of problems in interorganizational projects and could not be directly converted into relationship-specific risks and risk determinants, as they are quite generally formulated, require clarification and supplementation. It should be noted that problems cannot be directly translated into risks as the problem and the risk are not the same. After a probability is assigned to uncertainty, it transforms into risk [69]. Other risk definitions state that it is the probability of unwanted event with its severity. Risk character is dependent on the three factors: the event, its probability of occurrence and severity [70]. In this work, a more comprehensive risk definition according to FMEA was applied, in which in addition to the event, probability, and severity, the possibilities of detection were also considered. It should be emphasized that the omission of a significant risk or risk determinant in interorganizational projects implemented by engineering companies may result in a distortion of the risk analysis result.

\section{Proposed Approach}

The proposed approach consists of six steps, which are presented in Figure 1.

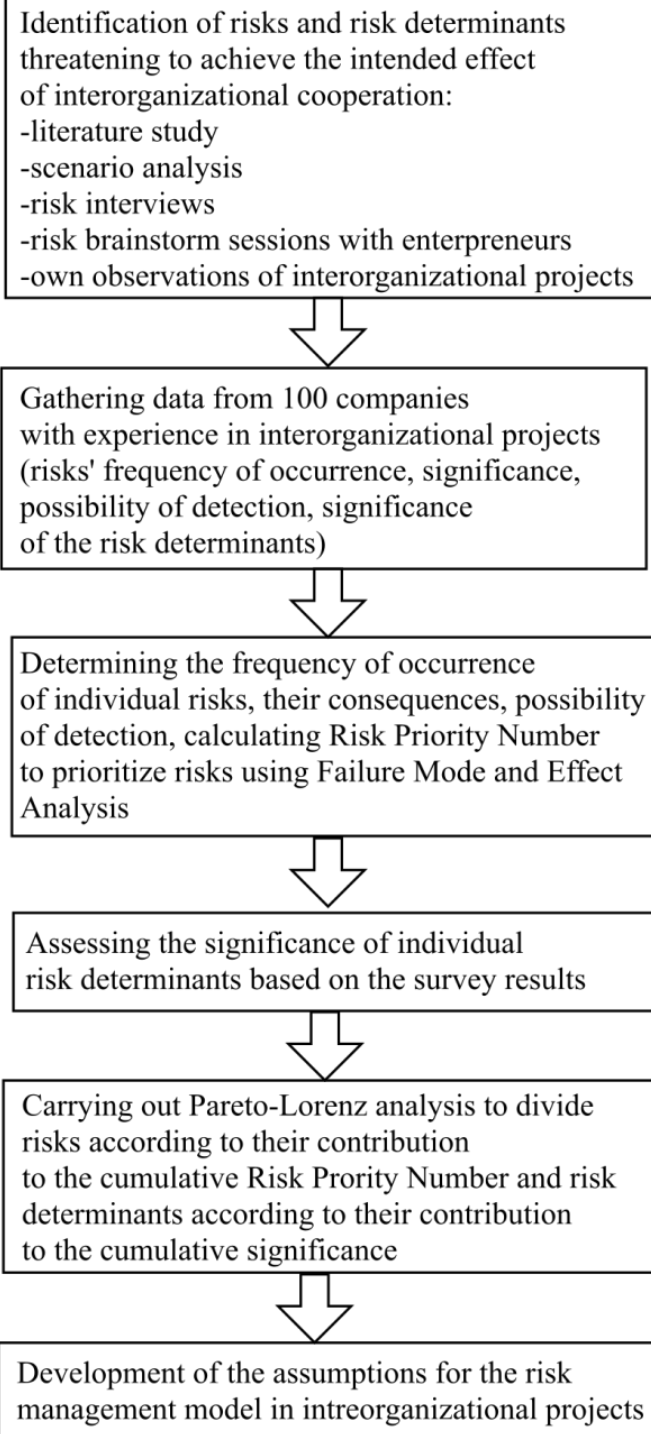

Gathering data from 100 companies with experience in interorganizational projects (risks' frequency of occurrence, significance, possibility of detection, significance of the risk determinants)

Determining the frequency of occurrence of individual risks, their consequences, possibility of detection, calculating Risk Priority Number to prioritize risks using Failure Mode and Effect Analysis

Assessing the significance of individual risk determinants based on the survey results

Carrying out Pareto-Lorenz analysis to divide risks according to their contribution to the cumulative Risk Prority Number and risk determinants according to their contribution to the cumulative significance

Development of the assumptions for the risk management model in intreorganizational projects

Figure 1. The proposed approach. 
In the proposed approach, FMEA technique was chosen to be applied, as it is often used to define, identify, and eliminate known or potential risks or failures. It provides valuable information needed for making decisions in the risk management process [71]. Traditional FMEA uses Risk Priority Number (RPN) to evaluate risk priority. It is a mathematical product of the frequency of a certain risk occurrence $(\mathrm{O})$, its consequences $(\mathrm{C})$, and possibilities of detection (D): $\mathrm{RPN}=\mathrm{O} \times \mathrm{C} \times \mathrm{D}$. It enables to obtain a ranking order among the identified risks. If the calculated RPN value for a certain risk is higher than others, it is associated with higher risk, more attention should be paid to its proper management [72].

In the proposed approach, it was decided to carry out Pareto-Lorenz analysis, which is one of the most popular traditional tools used in quality management, aiming to contribute to the rise in product quality level and make improvements in various processes [73]. The term "Pareto principle" was firstly used in 1941 by Joseph Juran who noticed that $80 \%$ of quality problems are caused by $20 \%$ of the identified causes [74]. This means that most causes lead to minor effects and focusing too much on that group of causes is not effective. Pareto-Lorenz analysis includes several steps: problem identification, data collection, identification of risks and risk determinants, ordering the risks/risk determinants in decreasing order according to the importance of their effects, developing a bar chart for these values (Pareto chart), calculating the cumulative value for each risks/risk determinant effect (RPN+, Significance+), developing a line chart for the cumulative value of each risk/risk determinant effect (Lorenz curve), analysing the diagram. It should be noticed that the $80 / 20$ or $70 / 30$ ratio does not always occur in the Pareto-Lorenz analysis, the proportion could be different, and it does not mean that there is an error in the analysis [75].

\subsection{Data Gathering}

Quantitative data on the risk of unfavourable interorganizational relations in interorganizational projects were obtained. The data was gathered from 100 Polish engineering companies with experience in interorganizational projects, i.e., have carried out at least one project together with another entity. Such a number of surveyed companies allowed for the development of a representative sample, which constituted a credible image of interorganizational relations occurring in projects jointly undertaken by several companies. The sample was selected arbitrarily: $34 \%$ of the surveyed enterprises had experience in interorganizational building construction projects (IBCP), 33\% of the surveyed enterprises in interorganizational projects in environmental engineering (IEEP) and $33 \%$ of the surveyed enterprises had experience in interorganizational socially responsible projects taken by engineering companies (ISRP). Building construction projects were defined as projects aiming to construct a building or a structure (excluding infrastructure and environmental engineering facilities). Environmental engineering projects were defined as projects aiming to develop infrastructure related to environmental protection. Socially responsible projects taken by engineering companies were understood as Corporate Social Responsibility (CSR) projects (defined in Section 2.2) carried out by engineering companies. Surveyed companies independently classified their projects to one of these three groups. Therefore, there were no situations where one project was classified into two groups at the same time. There was also no feedback from the respondents' showing problems with unambiguous assignment of projects to the appropriate group. Such a selection of the sample made it possible to compare the risk structure (the frequency of risk occurrence, risk consequences, possibility of risk detection, and Risk Priority Numbers) and the significance of risk determinants in the analysed groups. The samples in the three subgroups were selected randomly, which allowed for the elimination of bias in the selection of companies participating in the study.

To verify the answers given by the respondents to show their truthfulness, a control question was included in the survey, which was consistent with the content of another question, but different in form and expression. It allowed the verification of respondents' answers to RQ3 and to some extent to preclude deceptive responders. The contradiction in the gathered answers revealed the respondent's dishonesty, which also disqualified the rest of their answers, which they were not considered in further analysis. In addition, it was 
decided to carry out a pilot survey before the actual ones, to check the correctness of the survey procedure and validate the test tool.

The data was obtained from a total of 12,352 interorganizational projects (1602 IBC, 5804 IEEP, and 4946 ISRP). The time range of data collection was 4 November 202020 January 2021. In the questionnaire, the respondents were asked, among others, to indicate if the company participated in projects undertaken jointly by several entities (if not, they were excluded from the survey), the number of interorganizational projects on which their experience is based, and mark the type of projects (IBCP, IEEP, ISRP).

\subsection{Research Methodology}

The literature research presented in Section 2 revealed a number of problems in interorganizational projects, which were the basis for defining several relation specific risks and risk factors. In order to obtain a complete list of relation-specific risks and risk determinants, scenario analysis, brainstorm sessions, own observations of interorganizational projects were used.

To identify risks and risk determinants, 10 interorganizational building construction and environmental engineering projects, in addition to five interorganizational socially responsible projects were observed. In addition, brainstorming sessions conducted among 14 company employees supported the identification of risks and risk determinants. During the brainstorming session, the following problems were posed: What are the relationshipspecific risks associated with failure to achieve the intended benefit of interorganizational cooperation that occur in interorganizational projects? What are the mechanisms leading to the failure to achieve the intended benefit of interorganizational cooperation in interorganizational projects? The participants of the brainstorm session gave various answers to the stated problem, and the leader of the session (author of the paper) documented all their answers. Brainstorming allowed to gather-sometimes not obvious-proposals of risks and risk determinants that could be overlooked. The collected proposals were assessed in terms of their usefulness to develop a list of risks and mechanisms that may lead to failure to achieve the intended benefit of interorganizational cooperation.

In this study, the Computer-Assisted Telephone Interviewing (CATI) data collection technique was used, which, thanks to the lack of personal contact between the interviewer and the participants in the study, ensured both parties' safety and did not carry the risk of getting infected with COVID-19. In the telephone survey, the interviewer was trained, inter alia, not to suggest answers to respondents, not to mislead the respondents by reading the questions incorrectly.

\section{Results}

The risk identification stage allowed us to develop the first comprehensive lists covering 18 relationship-specific risks (Table 1 ) and 28 risk determinants (Table 2) in interorganizational projects taken by engineering companies. Risks were not equated with problems, but according to the comprehensive definition of risk in the FMEA method, they were the product of the frequency of occurrence, consequences and the possibility of detecting undesirable events. As a result of scenario analysis, brainstorm sessions, reviews of interorganizational problems and own observations of interorganizational projects, 18 new relationship-specific risks were defined. A total of 12 relationship-specific risks were identified based on brainstorm sessions, scenario analysis and own observation of interorganizational projects: X1, X5, 11, X13, X14, X15, X16, X17, and X18. Furthermore, some of the problems in interorganizational projects found in the literature were converted into relationship-specific risks, e.g., different objectives were converted into X2 (self-interest orientation), lack of communication and integration of the participants was converted into X3 (problems with communication and listening to each other), disproportion between contribution and dependency was included into X4 (no willingness to actually cooperate), bureaucracy was included and extended by $\mathrm{X} 9$ (conservative approach to problem solving), lack of cooperation history was included and extended in X10 (the lack of parties' experi- 
ence in the execution of similar projects) and lack of flexibility was included in risk X12 (lack of ability to react quickly to crisis situations).

Table 1. The frequency of relationship-specific risks occurrence $(\mathrm{O})$, their consequences $(\mathrm{C})$, possibility of detection (D), and the Risk Priority Number (RPN).

\begin{tabular}{|c|c|c|c|c|}
\hline Symbol & Risk & $\mathbf{O}$ & $\mathrm{C}$ & D \\
\hline $\mathrm{X} 1$ & Hiding internal problems and/or problems related to the joint venture & 3.05 & 3.14 & 8.43 \\
\hline $\mathrm{X} 2$ & Self-interest orientation & 4.36 & 3.01 & 7.95 \\
\hline X3 & Problems with communication and listening to each other & 2.23 & 2.59 & 8.06 \\
\hline$X 4$ & No willingness to actually cooperate & 1.53 & 2.19 & 8.65 \\
\hline X5 & Lack of willingness to share information and transparency of activities & 2.83 & 2.62 & 8.28 \\
\hline $\mathrm{X} 6$ & Confrontational collaborative environment & 2.14 & 2.23 & 8.59 \\
\hline$X 7$ & Lack of a good project coordinator & 3.02 & 3.06 & 7.88 \\
\hline $\mathrm{X} 8$ & Converting work problems into personal problems and vice versa & 1.69 & 1.64 & 9.04 \\
\hline X9 & Conservative approach to problem solving & 2.37 & 2.20 & 8.09 \\
\hline $\mathrm{X} 10$ & The lack of parties' experience in the implementation of similar projects & 2.46 & 2.77 & 7.74 \\
\hline $\mathrm{X} 11$ & Lack of ability to build beneficial relationships & 1.99 & 2.01 & 8.63 \\
\hline $\mathrm{X} 12$ & Lack of ability to react quickly to crisis situations & 2.27 & 2.67 & 8.78 \\
\hline $\mathrm{X} 13$ & Lack of party involvement & 2.32 & 2.50 & 8.65 \\
\hline $\mathrm{X} 14$ & Unfavourable and imprecise contract & 3.26 & 3.13 & 7.52 \\
\hline X15 & No clear way to make joint decisions & 2.02 & 2.66 & 8.27 \\
\hline $\mathrm{X} 16$ & No clear accountability framework & 2.26 & 2.63 & 8.16 \\
\hline $\mathrm{X} 17$ & No action strategy & 2.72 & 2.59 & 8.28 \\
\hline $\mathrm{X} 18$ & $\begin{array}{c}\text { Problems related to the origin of cooperating entities from different } \\
\text { organizational cultures }\end{array}$ & 2.57 & 1.80 & 8.90 \\
\hline
\end{tabular}

As a result of scenario analysis, brainstorm sessions, review on problems in interorganizational problems, and own observations of interorganizational projects, 28 new risk determinants were identified. A total of 16 new risk determinants were identified based on the brainstorm sessions, scenario analysis and own observation of interorganizational projects: D1, D3, D4, D5, D6, D10, D11, D15, D16, D17, D18, D19, D22, D23, D27, D28. Furthermore, some of the problems in interorganizational projects found in the literature were converted into risk determinants and explained in detail during the brainstorm sessions. Lack of cooperation history was explained in detail by D2 (no prior experience in interorganizational projects). Interdependencies were extended to D7 (dependence on another organization-concern, holding company, group of companies and related lack of full decision-making independence) and D12 (dependence on another entity). Communication problems were extended to D8 (communication problems between cooperating organizations) and D9 (communication problems within own organization). Different objectives were extended to D20 (very different partial goals) and D21 (different main goal). Unwanted relationship prioritization was clarified by D25 (various scales of operations of cooperating entities- cooperation dominated by stronger entity). Unified contract was extended to D14. High time and resources consumption was extended to D24. Relationship prioritization was translated into D25. Financial security was expressed by D26.

Table 1 presents the 18 identified individual risks along with the frequency of their occurrence (O), their consequences (C), and detection possibilities (D). They were assessed by respondents using a 10-point scale used in the Failure Mode and Effect Analysis (FMEA) method, where 1 means very rarely/very low impact/very high possibility of detection, and 10-commonly/very high impact/very low possibility of detection.

Table 3 shows the Risk Priority Numbers (RPN) for the analysed risks calculated for AAP, IBCP, EEP, and ISRP. 
Table 2. The significance of the identified risk determinants.

\begin{tabular}{|c|c|c|c|c|c|}
\hline \multirow[t]{2}{*}{ Symbol } & \multirow[t]{2}{*}{ Risk Determinants } & \multicolumn{4}{|c|}{ Significance } \\
\hline & & AAP & IBCP & IEEP & ISRP \\
\hline D1 & $\begin{array}{l}\text { Unfavourable reputation of entities based on their previous experiences } \\
\text { in interorganizational projects (e.g., the entity has a dishonest opinion, } \\
\text { the entity has in the past imposed their values and patterns on others) }\end{array}$ & 4.93 & 5.35 & 4.76 & 4.67 \\
\hline D2 & No prior experience of the entity in interorganizational projects & 3.56 & 4.15 & 3.52 & 3.00 \\
\hline D3 & $\begin{array}{l}\text { Different experiences of entities from previous cooperation (very good } \\
\text { leading to openness of the entity or bad leading to over-caution) }\end{array}$ & 4.55 & 4.09 & 5.18 & 4.39 \\
\hline D4 & $\begin{array}{l}\text { The project formula focused on the price, giving the possibility of } \\
\text { unfavourable relations occurrence: a competitor, not a co-worker }\end{array}$ & 3.64 & 3.79 & 3.88 & 3.24 \\
\hline D5 & $\begin{array}{l}\text { Personal relationships between employees of different entities } \\
\text { constituting a barrier to effective cooperation (e.g., conflict of interest) }\end{array}$ & 2.53 & 2.82 & 2.45 & 2.30 \\
\hline D6 & Personal ambitions of the entities & 3.11 & 3.21 & 3.18 & 2.94 \\
\hline D7 & $\begin{array}{l}\text { Dependence of one of the cooperating entities on another organization } \\
\text { (concern, holding company, group of companies) and the related lack of } \\
\text { full decision-making independence }\end{array}$ & 3.10 & 3.62 & 2.91 & 2.76 \\
\hline D8 & Communication problems between cooperating organizations & 3.44 & 3.85 & 3.21 & 3.24 \\
\hline D9 & Communication problems within own organization & 2.58 & 3.03 & 2.61 & 2.09 \\
\hline D10 & $\begin{array}{c}\text { Monopolization, duplication or incompleteness of cooperating } \\
\text { entities competences }\end{array}$ & 2.84 & 3.38 & 2.76 & 2.36 \\
\hline D11 & $\begin{array}{l}\text { Lack of trust due to the inability to build trust over the years, the rapid } \\
\text { need for cooperation between entities from the day of getting to know } \\
\text { each other }\end{array}$ & 3.13 & 3.53 & 3.33 & 2.52 \\
\hline D12 & $\begin{array}{c}\text { Dependence of the cooperating entity on another entity that } \\
\text { generates problems }\end{array}$ & 3.74 & 3.65 & 4.00 & 3.58 \\
\hline D13 & A contract with a disproportionately distributed risk & 4.38 & 4.79 & 4.33 & 4.00 \\
\hline D14 & $\begin{array}{c}\text { Imprecisely formulated contract regarding, for example, own } \\
\text { contribution of the entities, the responsibility of individual parties. } \\
\text { leading to disputes, manipulation of the meaning of these clauses; taking } \\
\text { advantage of legal complexities and ambiguous interpretation } \\
\text { of regulations }\end{array}$ & 4.30 & 4.29 & 4.39 & 4.21 \\
\hline D15 & $\begin{array}{l}\text { Imprecise contract clauses or lack of regulations in the contract regarding } \\
\text { intellectual property rights and rights to the results of R\&D works } \\
\text { created during the project }\end{array}$ & 3.84 & 3.53 & 4.18 & 3.82 \\
\hline D16 & $\begin{array}{l}\text { Lack of clear competence catalogue of the coordinating entity } \\
\qquad / \text { coordinating structure }\end{array}$ & 3.84 & 3.50 & 4.27 & 3.76 \\
\hline D17 & Lack of competent person who could be a good coordinator & 4.11 & 4.88 & 3.88 & 3.55 \\
\hline D18 & $\begin{array}{l}\text { Lack of preparation of the parties in the field of } \\
\text { interpersonal communication }\end{array}$ & 3.23 & 3.35 & 3.45 & 2.88 \\
\hline D19 & Lack of coordinating mechanisms developed together by the entities & 3.45 & 3.56 & 3.76 & 3.03 \\
\hline D20 & $\begin{array}{l}\text { Very different partial goals of the individual entities willing to cooperate } \\
\text { Different main goal of the entities willing to cooperate (e.g. desire for }\end{array}$ & 3.49 & 3.50 & 3.79 & 3.18 \\
\hline D21 & $\begin{array}{l}\text { profit, willingness to gain experience and references, willingness to } \\
\text { gain contacts) }\end{array}$ & 3.78 & 3.74 & 4.39 & 3.21 \\
\hline D22 & $\begin{array}{c}\text { Possibility of competition between cooperating entities (not disclosed } \\
\text { when signing a cooperation agreement) }\end{array}$ & 3.34 & 3.38 & 3.73 & 2.91 \\
\hline D23 & $\begin{array}{l}\text { Imprecise rules for providing information on the activities of each entity } \\
\text { and the scope. accuracy and detail of the information which should } \\
\text { be provided }\end{array}$ & 3.12 & 3.53 & 2.97 & 2.85 \\
\hline D24 & $\begin{array}{l}\text { A large number of projects in which the entity is involved, preventing } \\
\text { the appropriate level of involvement for a given project }\end{array}$ & 3.85 & 4.38 & 3.85 & 3.30 \\
\hline D25 & $\begin{array}{c}\text { Various scales of operations of cooperating entities (cooperation } \\
\text { dominated by a stronger entity) }\end{array}$ & 3.93 & 4.68 & 3.94 & 3.15 \\
\hline D26 & $\begin{array}{l}\text { Failure to carry out a preliminary due diligence of one of the cooperating } \\
\text { entities, leading to a lack of information about their poor } \\
\text { financial condition }\end{array}$ & 3.31 & 3.62 & 3.09 & 3.21 \\
\hline D27 & Individual operating strategy of cooperating entities instead of joint & 3.52 & 3.94 & 3.82 & 2.79 \\
\hline D28 & Forced remote work (e.g., due to epidemics. pandemics) & 2.52 & 3.00 & 2.45 & 2.09 \\
\hline
\end{tabular}

$\mathrm{AAP}$-interorganizational engineering projects in general, IBCP-interorganizational building construction projects, IEEP - interorganizational projects in environmental engineering, ISRP-interorganizational socially responsible projects taken by engineering companies. 
Table 3. Calculated Risk Priority Numbers (RPN) for the analysed relationship-specific risks.

\begin{tabular}{|c|c|c|c|c|c|}
\hline \multirow[t]{2}{*}{ Symbol } & \multirow[t]{2}{*}{ Risks } & \multicolumn{4}{|c|}{ RPN } \\
\hline & & AAP & IBCP & IEEP & ISRP \\
\hline $\mathrm{X} 1$ & Hiding internal problems and/or problems related to the joint venture & 80.73 & 59.53 & 77.04 & 101.30 \\
\hline $\mathrm{X} 2$ & Self-interest orientation & 104.33 & 137.16 & 105.19 & 86.89 \\
\hline $\mathrm{X} 3$ & Problems with communication and listening to each other & 46.55 & 106.67 & 38.23 & 34.01 \\
\hline $\mathrm{X} 4$ & No willingness to actually cooperate & 28.98 & 51.58 & 21.05 & 29.25 \\
\hline X5 & Lack of willingness to share information and transparency of activities & 61.39 & 73.23 & 66.60 & 52.70 \\
\hline X6 & Confrontational collaborative environment & 40.99 & 50.87 & 40.03 & 36.52 \\
\hline $\mathrm{X} 7$ & Lack of a good project coordinator & 72.82 & 164.00 & 48.78 & 65.64 \\
\hline $\mathrm{X} 8$ & Converting work problems into personal problems and vice versa & 25.06 & 28.70 & 16.08 & 32.66 \\
\hline X9 & Conservative approach to problem solving & 42.18 & 48.61 & 34.23 & 41.68 \\
\hline $\mathrm{X} 10$ & The lack of parties' experience in the execution of similar projects & 52.74 & 75.52 & 27.19 & 62.42 \\
\hline $\mathrm{X} 11$ & Lack of ability to build beneficial relationships & 34.52 & 52.10 & 26.64 & 37.49 \\
\hline $\mathrm{X} 12$ & Lack of ability to react quickly to crisis situations & 53.21 & 92.80 & 22.75 & 72.60 \\
\hline $\mathrm{X} 13$ & Lack of party involvement & 50.17 & 49.35 & 47.01 & 45.02 \\
\hline $\mathrm{X} 14$ & Unfavourable and imprecise contract & 76.73 & 119.97 & 43.91 & 82.49 \\
\hline X15 & No clear way to make joint decisions & 44.44 & 72.80 & 31.76 & 44.22 \\
\hline $\mathrm{X} 16$ & No clear accountability framework & 48.50 & 65.81 & 27.67 & 58.05 \\
\hline $\mathrm{X} 17$ & No action strategy & 58.33 & 73.10 & 40.57 & 66.98 \\
\hline $\mathrm{X} 18$ & $\begin{array}{c}\text { Problems related to the origin of cooperating entities from different } \\
\text { organizational cultures }\end{array}$ & 41.17 & 31.75 & 55.67 & 25.33 \\
\hline
\end{tabular}

$\mathrm{AAP}$-interorganizational engineering projects in general, IBCP-interorganizational building construction projects, IEEP-interorganizational projects in environmental engineering, ISRP-interorganizational socially responsible projects taken by engineering companies.

Respondents were also asked to provide and evaluate additional risks that were not mentioned in the survey. One of the surveyed companies gave additional "Not receiving remuneration" with the frequency of 10 points, the consequences of 10 points, and the possibility of detection 10 points. However, this problem was included as a risk determinant D26 in the survey.

Table 2 summarizes the results of the significance studies of the 28 identified risk determinants. They were assessed by the surveyed enterprises on a scale of 1-10 points. where 1 is very low and 10 is very high.

Carrying out Pareto-Lorenz analysis allowed us to divide the risks in three groups, according to their contribution to cumulative RPN (RPN+). Similarly, risk determinants were divided into three groups according to their contribution to cumulative significance (Significance+). Group A included the risks/risk determinants for which elimination is vital for risk reduction. Group B contained the risks/risk determinants for which significance is secondary. Group C included the risks/risk determinants which, if eliminated, could cause the least risk reduction. Figure 2 presents a Pareto-Lorenz chart for RPN for risks in interorganizational projects in all analysed companies. Figure 3 presents a ParetoLorenz chart for Significance of risk determinants in interorganizational projects in all analysed companies.

The Lorenz curves obtained as a result of risks and risk determinants analysis are flatter in their initial phase than the standard Lorenz curve. This means that there is a clear difference in the groups of causes (A, B, C), taking into account the criterion of the number of risks/risk determinants and the criterion of the effect value (RPN+/Significance+).

When carrying out Pareto analysis in terms of the number of risks, it can be seen that:

- $\quad 22 \%$ of risks generate $35 \%$ of effects (RPN+);

- $\quad$ next $28 \%$ of risks generate $28 \%$ of effects (RPN+);

- $\quad$ the remaining $50 \%$ of risks generate $37 \%$ effects (RPN+).

- When carrying out Pareto analysis in terms of the value of failure effects (RPN+):

- $\quad 67 \%$ of risks lead to $78 \%$ of effects $(\mathrm{RPN}+)$;

- $\quad$ next $22 \%$ of risks lead to $16 \%$ effects (RPN+);

- $\quad$ the remaining $11 \%$ of risks lead to $6 \%$ effects (RPN+). 


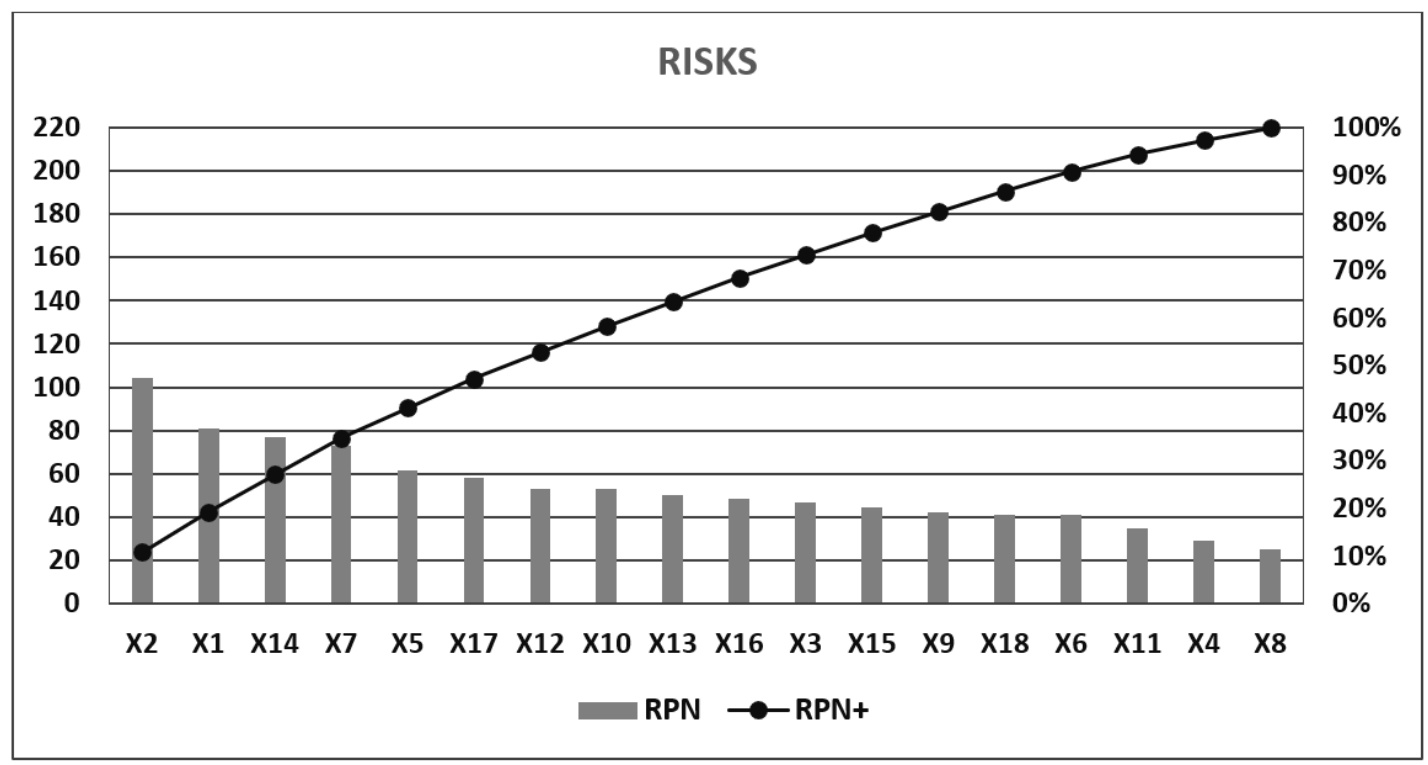

Figure 2. Pareto-Lorenz chart of RPN for RPN for risks in interorganizational projects in all analysed engineering companies.

\section{Risk determinants}

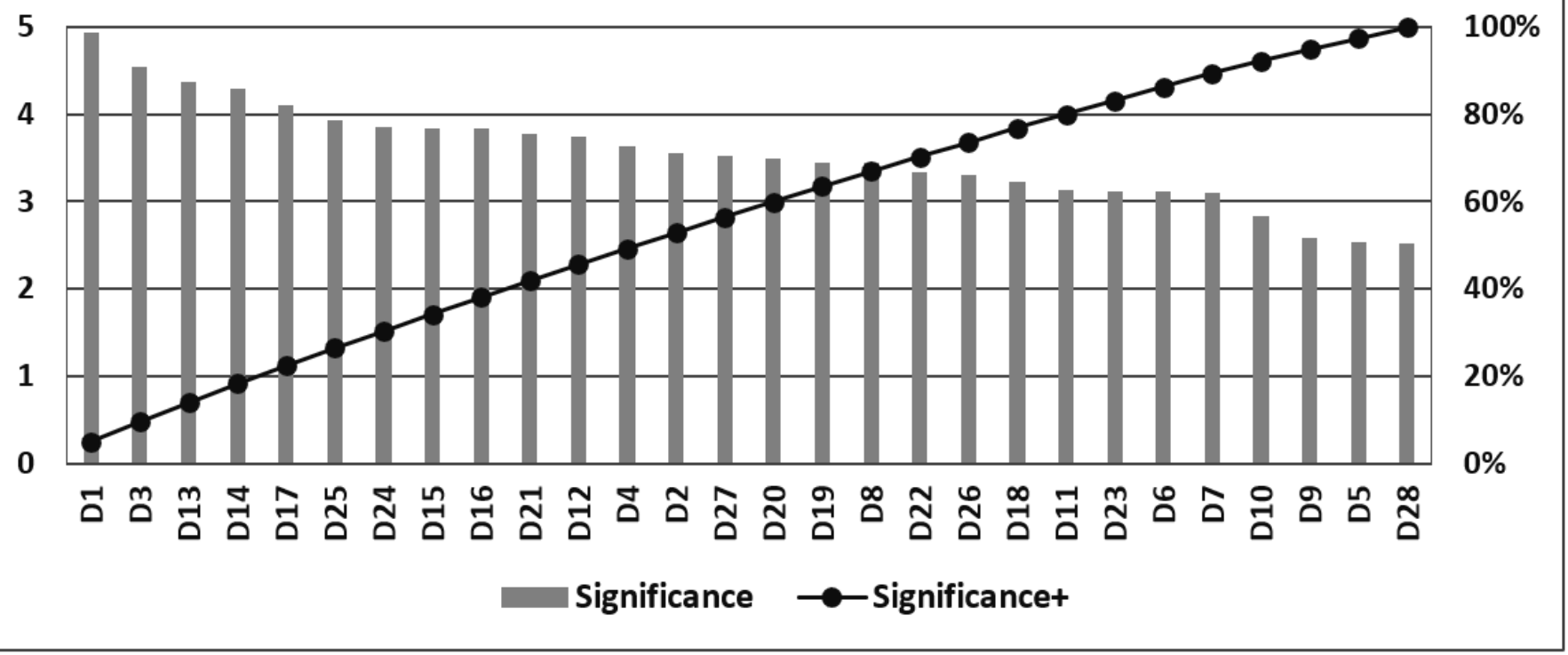

Figure 3. Pareto-Lorenz chart for Significance of risk determinants in interorganizational projects in all analysed engineering companies.

When carrying out Pareto analysis in terms of the number of risk determinants, it can be seen that:

- $\quad 21 \%$ of risk determinants generate $26 \%$ of effects (Significance+);

- next $29 \%$ of risk determinants generate $30 \%$ of effects (Significance+);

- $\quad$ the remaining $50 \%$ of risk determinants generate $34 \%$ effects (Significance+).

- When carrying out Pareto analysis in terms of the value of failure effects (Significance+),

- $\quad 75 \%$ of risk determinants lead to $80 \%$ of effects (Significance + );

- $\quad$ next $18 \%$ risk determinants lead to $15 \%$ effects (Significance+);

- $\quad$ the remaining $7 \%$ risk determinants lead to $5 \%$ effects (Significance+). 
Due to the fact that the analysis is intended to identify the most significant types of risks/risk determinants, the effect value criterion $(\mathrm{RPN}+$, Significance+) should not be taken uncritically into account. The criterion of the number of risks/risk determinants would be more interesting in the considered cases. Focusing on identification of the most significant types of risks/risk determinants, the criterion of the number of risks/ risk determinants was considered in Pareto-Lorenz analysis.

Therefore, it was assumed that group A in Pareto-Lorenz analysis should include up to $22 \%$ of risks types $(X 2, X 1, X 14, X 7)$, group $B$ the next $28 \%(X 6, X 17, X 12, X 10, X 13)$, and $\mathrm{C}$ the remaining 50\% (X16, X3, X15, X9, X18, X6, X11, X4, X8). Group A in Pareto-Lorenz analysis should include up to $21 \%$ of risk determinant types (D1, D3, D13, D14, D17, D25), group B next 29\% (D24, D15, D16, D21, D12, D4, D2, D27), and C the remaining 50\%.

In addition to the Pareto-Lorenz diagrams for risks and risk determinants for all analysed projects (AAP), diagrams were also drawn for individual groups (IBCP, IEEP, ISRP). Due to their ampleness, they will not be presented in this work, but the conclusions resulting from their analysis will be discussed.

The risk factors $\mathrm{X} 2, \mathrm{X} 14, \mathrm{X} 1, \mathrm{X} 7$, and $\mathrm{X} 5$ were the most frequent in all analysed projects. The most significant consequences were associated with the occurrence of risk factors $X 1$, $\mathrm{X} 14, \mathrm{X} 7, \mathrm{X} 2$, and X10. The risk factors X8, X18, X12, X13, X4, and X11 had the lowest possibility of detection in the analysed projects, therefore one should look for other risk treatment options. The highest Risk Priority Number was obtained for the following risk factors: X2, X1, X14, X7, and X5. It means that they should be a subject of particular care when managing risk.

It was found out that two different risks have similar $\mathrm{RPN}$ values (e.g., $\mathrm{RPN}(\mathrm{X} 15)=44.44$ and $\mathrm{RPN}(\mathrm{X} 9)=42.18)$, but they have various interpretations and diverse semantic risk implications. X15 possesses a higher risk than X9, although its frequency of occurrence was higher than for X15. It is caused by different values of consequences and possibilities of detection. In extreme cases, it could result in underestimating or even ignoring of an event associated with high risk, which occurrence may generate high costs. That is why it is vital to assess and include in the risk assessment model the risks' possibilities of occurrence, their consequences, and possibility of detection.

It was found out that the risk prioritization (RPN) changes in function of the type of projects. Figure 4 shows comparison of the results of RPN for individual risks in the three analysed groups (IBCP, IEEP, ISRP) and in all analysed projects (AAP).

The highest RPNs for individual risks were obtained for companies whose experience was based on interorganizational projects in construction (IBCP), except for X1 and X8, for which the highest RPNs were obtained for companies whose experience was based on interorganizational CSR projects (ISRP). For companies with experience in ISRP, RPN values for individual, risks were generally lower than for companies with experience in IBCP, except for $\mathrm{X} 2, \mathrm{X} 3, \mathrm{X} 6$, and $\mathrm{X} 13$, for which the risks were higher for companies with experience in IEEP than in ISRP, as well as $\mathrm{X} 1$ and $\mathrm{X} 8$, for which RPN for ISRP were the highest among all analysed groups. The lowest RPN values were generally obtained for individual risks for companies which experience is based on IEEP, except for X1, X2, X3, X5, X6, X13 and X18, for which the lowest RPNs were obtained for companies whose experience was based on inter-organizational CSR projects (ISRP). It can be noticed that X2 is among the most important risks for all analysed types of projects. Risk X14 is among the most important risks both in IBCP and ISRP, and X1 both in IEEP and ISRP.

As a result of the research, the mechanisms determining the occurrence of unfavourable interorganizational relations in interorganizational projects were discovered. Research has shown that the mechanisms determining the occurrence of unfavourable interorganizational relations of the highest significance (included in the group A according to the Pareto-Lorenz analysis taking the criterion of number of risk determinants) include: D1 (unfavourable reputation of entities based on their previous experiences from jointly implemented projects the entity has in the past imposed its values and patterns of action on others); D3 (various experiences of entities from previous cooperation (very good, lead- 
ing to the entity's openness or bad, leading to excessive caution); D13 (a contract with a disproportionately distributed risk); D14 (imprecisely formulated contract); and D17 (no competent person who could be a good coordinator). Risk determinants leading to the occurrence of less significant unfavourable interorganizational relationships (classified as group B according to the Pareto-Lorenz analysis) include: D25 (different scale of activities of cooperating entities (cooperation dominated by the stronger entity); D24 (a large number of projects in which the entity is involved, preventing the proper level of involvement for a given project); D15 (imprecise contract clauses or lack of regulations in the contract regarding intellectual property rights and rights to the results of R\&D works created during the project); D16 (no clear competence catalogue of the coordinating entity /coordinating structure); D21 (different main goal of the entities willing to cooperate); D12 (dependence of the cooperating entity on another entity that generates problems); D4 (the project formula focused on the price); D2 (no previous experience of the entity in interorganizational projects); and D27 (individual operating strategy of cooperating entities instead of joint). The remaining mechanisms were included in group $\mathrm{C}$ according to the Pareto-Lorenz analysis.

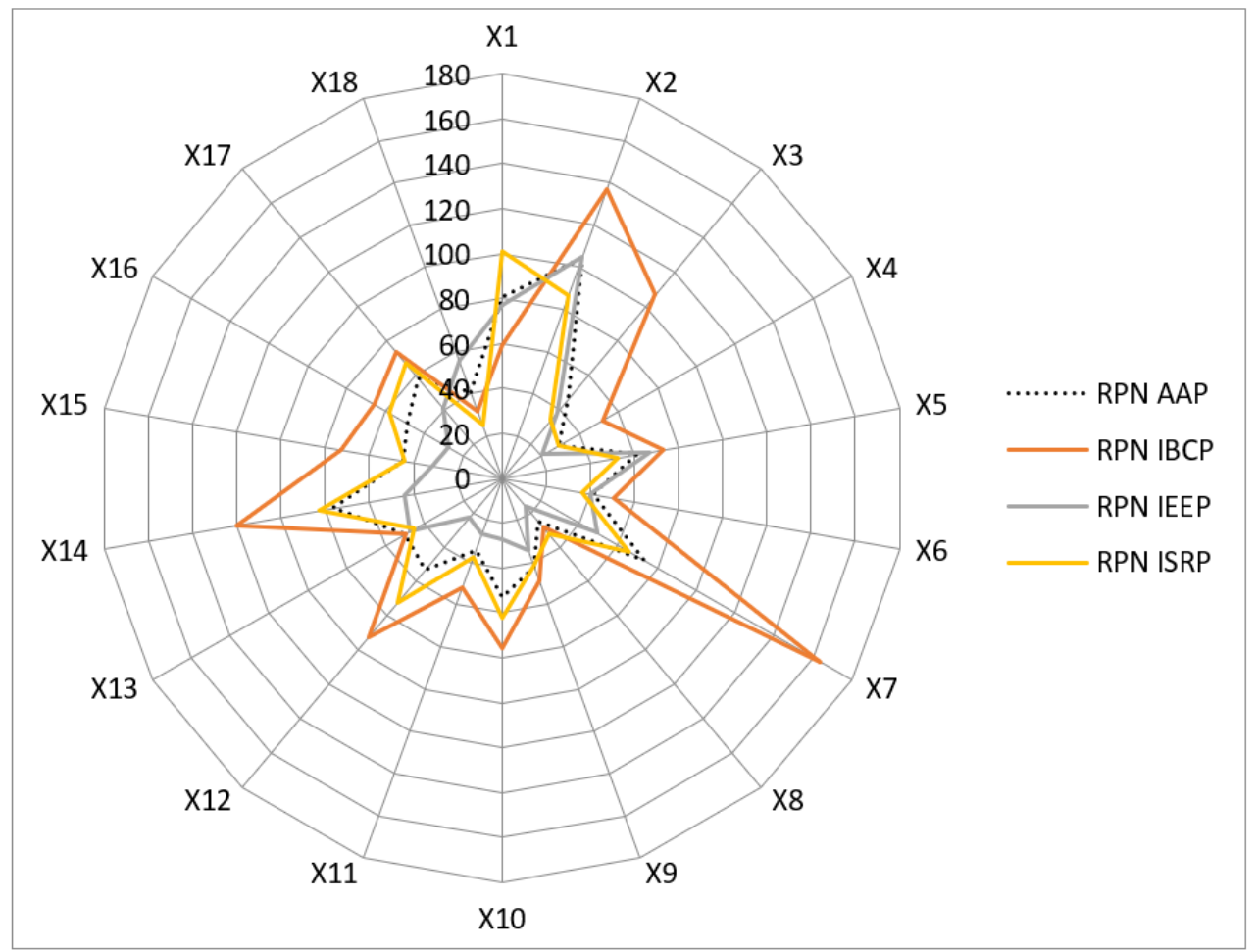

Figure 4. Comparison of the results of RPN for individual risks in the three analysed groups (IBCP, IEEP, ISRP) and all analysed projects (AAP).

Figure 5 shows comparison of the results of significance for individual risk determinants in the three analysed groups (IBCP, IEEP, ISRP, and AAP).

When analysing the risks in individual groups (IBCP, IEEP, ISRP), it can be concluded that the group A according to the Pareto-Lorenz analysis of IBCP includes the following risks: $X 7, X 2, X 14$, and $X 3$. It means that their elimination is vital for risk reduction. Group $B$ includes the following risks: X12, X10, X5, X17 and X15. When carrying out the ParetoLorenz analysis for the IEEP group, it can be noticed that the risks $\mathrm{X} 2, \mathrm{X} 1, \mathrm{X} 5$, and $\mathrm{X} 18$ belong to group $\mathrm{A}$, while the risks X7, X13, X14, X17 and X16 belong to group $\mathrm{B}$. When carrying out the Pareto-Lorenz analysis for the ISRP group, it can be concluded that the risks group $\mathrm{A}$ included $\mathrm{X} 1, \mathrm{X} 2, \mathrm{X} 14$, and X12, while group $\mathrm{B}$ included $\mathrm{X} 17, \mathrm{X} 7, \mathrm{X} 10, \mathrm{X} 16$ and X5. 


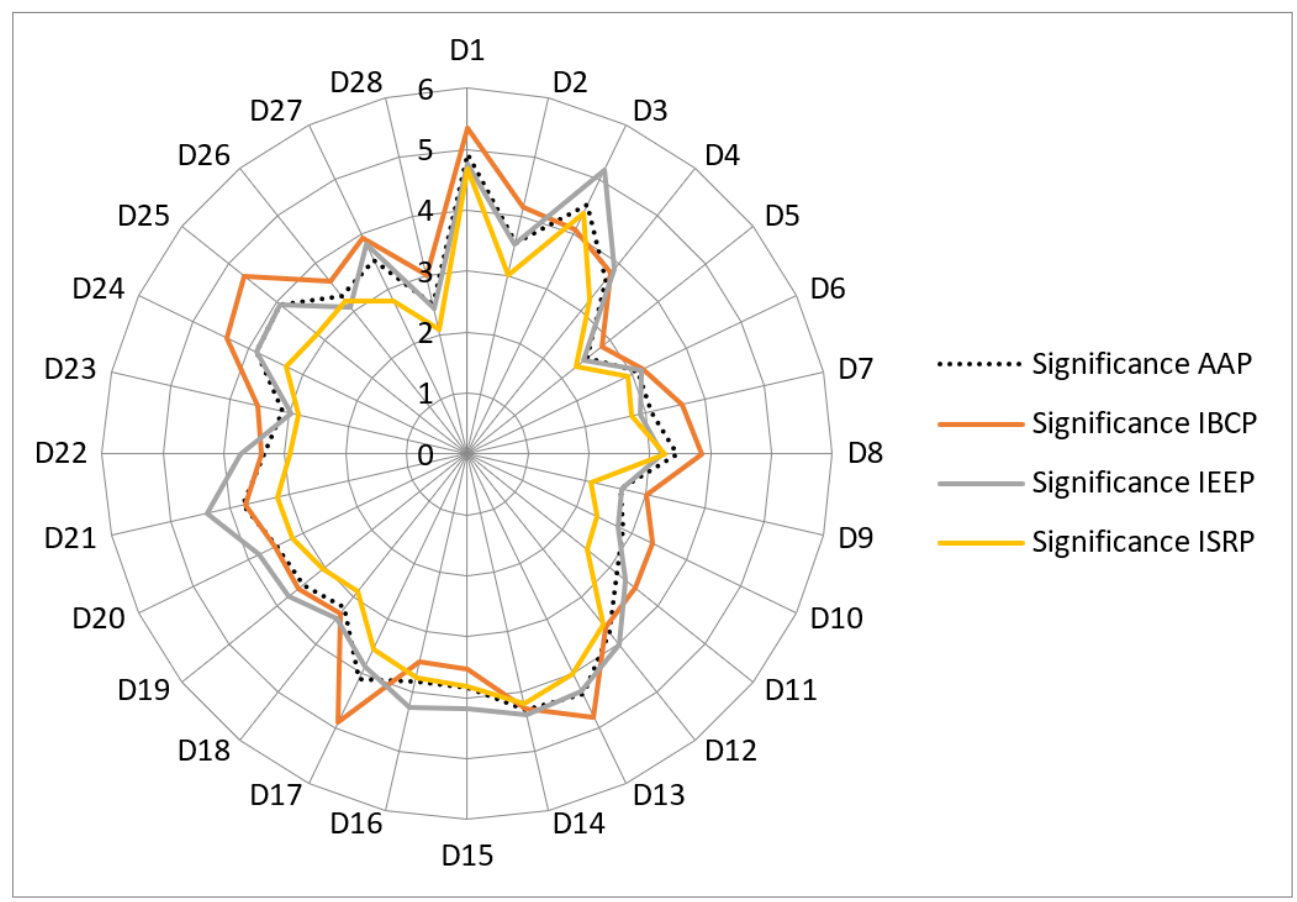

Figure 5. Comparison of the results of significance for individual risk determinants in the three analysed groups (IBCP, IEEP, ISRP, and AAP).

It was also found out that the risk determinants' significance prioritization changes in function of the type of project. When analysing the results of the Pareto-Lorenz analysis for the significance of risk determinants in individual groups, it can be seen that the group A in IBCP includes the following risk determinants: D1, D17, D13, D25, D24, and D14 and group B: D2, D3, D27, D8, D4, D21, D12, and D7. Group A in IEEP includes the following risk determinants: D3, D1, D14, D21, D13, and D16. Group B in IEEP includes the following determinants: D15, D12, D25, D4, D17, D24, D27, and D20. The group A in ISRP includes: D1, D3, D14, D13, D15, and D16. The group B in ISRP includes the following determinants: D12, D17, D24, D4, D8, D21, D26, and D20.

When analysing individual risk determinants, it can be noticed that the significance of the risk determinants D1, D2, D5-D11, D13, D17, D23-D28 was rated the highest by companies with experience in IBCP. On the other hand, the risk determinants D3, D4, D12, D14, D15, D16, D18-D22 were rated the highest by enterprises that were engaged in IEEP. Noteworthy is D28 (forced remote work, e.g., due to epidemics, pandemics), which is a new risk determinant defined on the basis of recent difficult experiences with the COVID pandemic. It was found out, that IBCP were the hardest hit by it.

Based on the research, assumptions were developed for the theoretical risk management model, the development of which will be the subject of further research:

- The need to take into account 18 identified risk factors and their probability of occurrence, consequences, and the possibility of detection.

- The need to connect individual risk factors with logical gates of the or type, because the occurrence of any of them is sufficient to not achieve the intended benefit of interorganizational cooperation.

- The need to include in the model the risk determinants belonging to groups A, B, and $\mathrm{C}$ according to the Pareto-Lorenz analysis (due to the flat Lorenz curve and lack of clear regularity that a narrow group of causes generates the highest RPN values). 


\section{Discussion}

In this section answers to research questions were given and related to the literature. Moreover, the limitations of the proposed approach and future research directions were discussed.

\subsection{RQ1: Which Relationship-Specific Risk Threatening to Achieve the Intended Benefit of Interorganizational Cooperation Is the Most Frequent in Interorganizational Projects Taken by Engineering Companies, has the Greatest Consequences and the Lowest Detection Possibilities?}

It was found that risk X2 (self-interest orientation) is the most frequent in interorganizational project taken by engineering companies. This is in line with the literature, where it was stated that the elimination of opportunism and self-interest is conducive to achieving trust in the organization [76], which is considered as one of important attribute of relationship quality $[15,40]$. Risk X2 results, to a large extent, from different objectives of cooperating entities, which has already been mentioned in the literature as a barrier to the introduction of collaborative interorganizational relationships in the construction industry [77]. This is in line with the literature, where it was stated that mutual goals are attributes of relationship quality in the construction industry [78], so their lack therefore influences collaboration and relationships. However, it was not known from the literature that this risk is characterized by the highest frequency of occurrence in interorganizational projects taken up by engineering companies.

Furthermore, the study revealed that risk X1 (hiding internal problems and/or problems related to the joint venture) had the greatest consequences in all analysed interorganizational projects taken up by engineering companies. X1 is related to a lack of trust and honesty. In the literature, trust and opportunism problems were included in relationship determinants as negative attributes of relationship quality in the construction industry [79]. Moreover, in the literature it was stated that trust cannot exist without honesty and proper communication [40]. However, from the literature, it was not known that this risk is characterized by such high consequences for interorganizational projects taken up by engineering companies.

The study revealed that attention should also be paid to X8 (converting work problems into personal problems and vice versa), which had the lowest detection possibilities in all analysed in interorganizational projects taken up by engineering companies. This is, to some extent, in line with the literature, where it was stressed that performance satisfaction is vital to project success [80], so it can happen that dissatisfaction related to problems with the implementation of the project will lead to the occurrence of tensions and personal conflicts between workers. This issue is related to the personality, attitude, and interpersonal skills of workers; therefore, its detection possibilities may be limited. The issue of assessing detection possibilities for relation-specific risks in interorganizational projects has not been taken up so far in the literature.

Therefore, these three relation-specific risks $(\mathrm{X} 2, \mathrm{X} 1$, and $\mathrm{X} 8)$ should be a subject of careful risk management. The study shows that it is worth analysing three factors that determine the character of the risk: frequency of occurrence, its consequences and detection possibilities, as risks having similar RPN can have various interpretations and diverse semantic risk implications. That is why attention should be paid not only to risks which have received the highest RPN, but also to those risks which have high frequency of occurrence, consequences, and low detection possibilities.

\subsection{RQ2: Which Relationship-Specific Risks Threatening to Achieve the Intended Benefit of} Interorganizational Cooperation had the Highest Risk Priority Number in Engineering Interorganizational Projects in General (AAP) and in Three Specified Groups: Interorganizational Building Construction Projects (BCP), Interorganizational Projects in Environmental Engineering (IEEP), and in Interorganizational Socially Responsible Projects (ISRP)?

In order to prioritize the risk value, three components determining the risk character (frequency of occurrence, consequences, and detection possibilities) were taken into account and RPN was calculated. The study revealed that the highest RPN was obtained for X2 
(self-interest orientation) in interorganizational projects taken up by engineering companies. A high RPN value in this case results from the relative high values for the risk components (the highest occurrence among all risks, significant consequences, and little possibility of detection). This is to some extent in line with the literature, where it was stated that the elimination of self-interest supports the achievement of trust in the organization [76], which is an important attribute of relationship quality $[15,40]$. However, it was not known from the literature that this risk has the first priority (characterized by the highest RPN) in interorganizational projects taken up by engineering companies.

In addition, it was found that the risk prioritization (RPN) changes in function of the type of project. Pareto-Lorenz analysis revealed the most significant risks in various types of interorganizational projects, for which elimination is vital for risk reduction. In the case of interorganizational building construction projects, these include: X7 (lack of good project coordinator), X2 (self-interest orientation), X14 (unfavourable and imprecise contract), and X3 (problems with communication and listening to each other). These risks are associated with a lack of facilitators aiming to overcome the difficulties generated by barriers to the introduction of collaborative interorganizational relationships in the construction industry. These facilitators were indicated in the literature, but in terms of promoting the quality of relationships, not in terms of risk. Moreover, it has not previously been identified in the literature which risks associated with IBCP are the greatest. Thus, $X 7$ is connected with a lack of facilitators, known in the literature as mutual coordination [80], X2 with a lack of facilitators called alignment of interests and objectives [81], X14 with a lack of facilitators called clear contract [51] and clearly defined responsibilities [82], and X3 with a lack of facilitators called effective communication [81].

In the case of interorganizational environmental engineering projects (IEEP), the most significant risks included: X2 (self-interest orientation); X1 (hiding internal problems and/or problems related to the joint venture); X5 (lack of willingness to share information and transparency of activities); and X18 (problems related to the origin of cooperating entities from different organizational cultures). Although the IEEPs have been separated from the AAPs group and constitute an individual group from the IBCPs, their greatest risks are also somewhat reflected in the lack of certain facilitators of relationship quality in the broadly understood construction industry. $\mathrm{X} 2$ is associated with a lack of facilitators, referred to in the literature as alignment of interest and objectives [81], X1 with a lack of openness [57], X5 with a lack of knowledge sharing [83] and information sharing [52], and X18 with a lack of familiarity with organizational norms and behaviours [44]. However, in the literature, it has not previously been assessed which risks associated with IEEP are the greatest.

In the case of socially responsible interorganizational projects taken by engineering companies (ISRP), the most significant risks included X1 (hiding internal problems and/or problems related to the joint venture), X2 (self-interest orientation), X14 (unfavourable and imprecise contract), and $\mathrm{X} 12$ (lack of ability to react quickly to crisis situations). It has already been discussed in this work why the risks X1, X2, and X14 are in line with the lack of facilitators aiming to overcome difficulties generated by barriers to the introduction of collaborative interorganizational relationships in the construction industry, which were given in the literature. It can be concluded that relationship facilitators in engineering companies are similar to those in the broadly understood construction industry, and a lack of these facilitators translates well into risks in various engineering projects, not only in construction.

The study revealed that the highest Risk Priority Numbers for individual risks were generally obtained for interorganizational building construction projects, lower for interorganizational socially responsible projects, and the lowest for interorganizational environmental engineering projects. This means that careful risk management is particularly important in the case of construction projects but should not be underestimated in the case of the other analysed types of projects. It is worth mentioning that environmental engi- 
neering projects and socially responsible projects are aimed at implementing sustainable practices by definition, which translates into lower risks obtained for these types of projects.

5.3. RQ3: Which Relationship-Specific Risk Determinants for Failure to Achieve the Intended Benefit of Interorganizational Cooperation were the Most Important in Interorganizational Engineering Projects in General (AAP), and in Three Specified Groups (IBCP, IEEP, ISRP)

It was also found that the most significant risk determinant in all the analysed projects is D1 (unfavourable reputation of entities based on their previous experiences). It is to some extent in line with the lack of facilitators aiming to overcome the difficulties generated by barriers to the introduction of collaborative interorganizational relationships in the construction industry, called in the literature previous experience in partnering projects [53]. It should be a subject of particular attention when managing risk in interorganizational projects taken up by engineering companies.

The Pareto-Lorenz analysis also revealed the most significant types of risk determinants in various types of interorganizational projects taken by engineering companies, the elimination of which is vital for risk reduction. In the case of IBCP, the most significant risk determinant is D1 (unfavourable reputation of entities), in the case of IEEP it is D3 (different experiences of entities from previous cooperation), and in the case of ISRP it is D1. It can be seen from the results of the Pareto-Lorenz analysis that D1 (unfavourable reputation of entities), D13 (a contract with a disproportionately distributed risk) and D14 (imprecisely formulated contract) are among the six most significant risk determinants in each of the three analysed groups (IBCP, IEEP and ISRP). D1 is, to some extent, in line with a lack of facilitator aiming to overcome difficulties generated by barriers to the introduction of collaborative interorganizational relationships in the construction industry, referred to in the literature as previous experience in partnering projects [53]. D13 is in line with the lack of one of the drives that motivate firms to set up collaborative interorganizational relationships in the construction industry, referred to in the literature as sharing risks and rewards [44]. D14 is in line with the lack of facilitators aiming to overcome difficulties generated by barriers to the introduction of collaborative interorganizational relationships, referred to in the literature as clear contract [51] and clearly defined responsibilities [82]. Moreover, there are some significant risk determinants, which are among the most important in each specific group, e.g., D24 (a large number of projects in which the entity is involved, preventing the appropriate level of involvement for a given project) is widely common in practice in building construction projects, whereas D3 (different experiences of entities from previous cooperation) and D16 (lack of clear competence catalogue of the coordinating entity) are highly rated both in IEEP and ISRP. D24 is related to a lack of commitment, whereas commitment in the literature is considered a cornerstone of the development of relationships in construction [40]. D3 is to some extent in line with a lack of facilitator, aiming to overcome difficulties generated by barriers to the introduction of collaborative interorganizational relationships in the construction industry, referred to in the literature as previous experience in partnering projects [53]. D16 is in line with the literature, where it was stated that coordination problems are common and influence performance and productivity in construction projects [84]. However, from the literature it was not known which risk determinants are the most significant for a certain group of projects.

\subsection{Limitations}

The main limitation of the applied FMEA technique is that the ranks of the frequency of occurrence, consequences, and detection possibilities of individual risks based on the results of the survey, representing a statistical approach. Although they present a correct illustration of the statistical view of risks and are satisfactory for preliminary risk assessment for many interorganizational projects, they may not be appropriate for each specific interorganizational project. This means that the risk assessment may not always be accurate, which could be particularly visible in a case of projects in specific industries which, due to their specificity, statistically differ from the projects analysed in this work, e.g., oil and 
gas industry, automotive industry, and IT industry. Therefore, interorganizational projects in such specific industries could be the subject of future research, in which the research methodology proposed in this paper could be applied. Although the research is based on 12,352 interorganizational projects from 100 Polish engineering companies, the results can be considered universal, because various procurement systems are currently used in Poland, a lot of projects are executed in international cooperation or by international concerns, and many CSR projects implemented in Poland reflect foreign patterns. Furthermore, the list of 18 risks and 28 risk determinants is universal and can be applied in any project carried out worldwide. In addition to this, the proposed methodology is universal and can be applied to future detailed research to determine the impact of the country specificity, procurement system, and enterprise business size on the perception of risks and risk determinants in interorganizational engineering projects.

\subsection{Future Research Directions}

Further research is aimed at developing a new risk assessment model dedicated to interorganizational projects, in which Fuzzy Fault Tree analysis will be applied. In this model, the 18 risks identified in this work, as well as the risk determinants from groups A, B, and C, will be used. They will be assessed by a group of experts familiarized with the analysed project specificity. It will enable risk assessment taking into consideration 18 identified risks and 28 risk determinants, as well as the specificity of the analysed project. It is expected that the application of the fuzzy sets theory in that model will allow to lower the lack of precision and the problems in gaining the crisp values of the basic events probability, which are encountered in the conventional Fault Tree Analysis. It is expected that the application of the fuzzy sets theory in that model will allow to lower the lack of precision and the problems in gaining the crisp values of the basic events probability, which are encountered in the conventional Fault Tree Analysis, as it was proved in [85]. It is also planned to develop machine learning models to predict risk in interorganizational construction projects. In [86], it was found out that machine learning models are efficient, fast and robust in risk prediction for Horizontal Directional Drilling projects. Moreover, new research is planned to determine the differences in perceiving risks and risk determinants in interorganizational engineering projects in various countries, in large, medium, and small-size civil engineering enterprises, and for projects executed in various procurement systems.

\section{Conclusions}

The results of the research carried out in this work showed that the execution of interorganizational projects is associated with relationship-specific problems that may threaten to achieve the intended benefit of interorganizational cooperation. Therefore, it is important to conduct a comprehensive risk assessment before starting an interorganizational project. The research carried out in this paper made it possible to develop assumptions for such a model. It is expected that the introduction of a comprehensive risk management model will result in a decrease in the number of claims, disputes, misunderstandings, and issues during the execution of the interorganizational project. It will support sustainable project management in interorganizational engineering projects and increase their sustainability.

This is the first work on relation-specific risks and risk determinants in interorganizational projects taken up by engineering companies. In this work, risks were developed after assigning frequency of occurrence, consequences, and possibilities of detection to unwanted events. The literature study on the problems in interorganizational projects was a basis for defining several risks and risk determinants. Moreover, brainstorm sessions, scenario analysis, and own observations of interorganizational projects were used to identify and define a novel, comprehensive list of risks and risk determinants, which was not found in the literature. In this work, 18 risks were identified that threaten to achieve the intended benefit of interorganizational cooperation. Their frequency of occurrence, consequences, possibility of detection, and Risk Priority Numbers were assessed. Additionally, 28 risk 
determinants were identified and their significance was assessed. The proposed approach was effective for surfacing the most significant relation-specific risk determinants and the highest risks in interorganizational projects.

It was found that risk $\mathrm{X} 2$ (self-interest orientation) is the most frequent, $\mathrm{X} 1$ (hiding internal problems and/or problems related to the joint venture) has the greatest consequences, and X8 (converting work problems into personal problems and vice versa) has the lowest detection possibilities in all analysed in interorganizational projects taken up by engineering companies. The study revealed that the highest Risk Priority Number was obtained for X2 (self-interest orientation) in interorganizational projects taken up by engineering companies. Additionally, the study revealed that the most significant risk determinant in all analysed projects is D1 (unfavourable reputation of entities based on their previous experiences). Three types of interorganizational projects were analysed: building construction projects, environmental engineering projects, and socially responsible projects. In the case of interorganizational building construction projects the most significant risk determinant is also D1, in the case of interorganizational environmental engineering projects-D3 (different experiences of entities from previous cooperation), and in the case of interorganizational socially responsible projects taken up by engineering companies-D1. They should be a subject of particular care when managing risk.

The study revealed that the highest Risk Priority Numbers for individual risks were generally obtained for interorganizational building construction projects, lower for interorganizational socially responsible projects, and the lowest for interorganizational environmental engineering projects. This means that careful risk management is particularly important in the case of construction projects but should not be underestimated in the case of the other types of projects analysed. It is worth mentioning that environmental engineering projects and socially responsible projects are aimed at realizing sustainable practices by definition, which translates into lower risks obtained for these types of projects.

The contribution of this paper to project management practice is to provide a novel and comprehensive list of relation-specific risks and risk determinants that threaten to achieve the intended benefit of interorganizational projects, as well as to provide the results of the quantitative risk assessment. It aims to give a helping hand to managers and all parties involved in such projects to consider a number of significant risks and risk determinants, preventing omitting significant risk or risk determinant at the risk assessment stage. It should be emphasized that the omission of a significant risk or risk determinant in interorganizational projects implemented by engineering companies may result in a distortion of the risk analysis result. The results of the FMEA and Pareto-Lorenz analysis made it possible to draw the attention of managers and all parties involved in interorganizational projects to the risks that are most frequent, associated with the most severe consequences, have the lowest possibility of detection, and those that are characterized by the highest risk (highest RPN). It also allowed to pay attention to those risk determinants that received the highest significance in the study.

The main contribution to the body of knowledge of this work is as follows:

- Providing a novel and comprehensive list of 18 relation-specific risks determining failure to achieve the intended benefit of interorganizational cooperation in engineering projects-risks were presented in Table 1.

- Assessment of risks' frequency of occurrence, significance, possibility of detection, and the Risk Priority Number associated with the occurrence of individual risks on the basis of data obtained from 100 companies with experience in interorganizational cooperation-it revealed various risks interpretations as well as diverse semantic risk implications, and confirmed the legitimacy of the comprehensive inclusion of 18 risks in the risk assessment model dedicated to inter-organizational projects taken by engineering companies.

- Gathering data from 100 companies with experience in interorganizational projects (the analysed companies have carried out a total of 12,352 projects in cooperation with other entities)—it enabled carrying out quantitative risk and risk determinants assessment. 
- Identification of 28 risk determinants (mechanisms) conditioning failure to achieve the intended benefit of interorganizational cooperation in engineering projects-a novel, comprehensive list of risk determinants was presented in Table 2.

- Assessment of the significance of determinants (mechanisms) conditioning failure to achieve the intended benefit of interorganizational cooperation on the basis of data obtained from 100 companies with experience in interorganizational cooperationit enabled the prioritization among risk determinants and focusing risk managers attention on the most significant risk determinants.

- Development of assumptions for the risk management model in interorganizational engineering projects - such a model will give a helping hand to all managers and practitioners aiming to develop successful interorganizational projects.

Funding: This work is based on research from a single research activity Miniatura 4, funded by the National Science Centre in Poland, Project title: Examination of mechanisms and risk factors determining the failure to achieve the intended benefit of inter-organization cooperation, Project registration No.: 2020/04/X/HS4/00287.

Institutional Review Board Statement: Not applicable.

Informed Consent Statement: Informed consent was obtained from all subjects involved in the study.

Data Availability Statement: Data available in a publicly accessible repository that does not issue DOIs. This data can be found here: [https://www.kaggle.com/mariakrechowicz/unfavorableinterorganizational-relations] accessed on 30 September 2021.

Conflicts of Interest: The author declares no conflict of interest.

\section{References}

1. Jones, C.; Lichtenstein, B.B. Temporary inter-organizational projects. In The Oxford Handbook of Inter-Organizational Relations; Oxford University Press: Oxford, UK, 2008.

2. Stjerne, I.S.; Söderlund, J.; Minbaeva, D. Crossing times: Temporal boundary-spanning practices in interorganizational projects. Int. J. Proj. Manag. 2019, 37, 347-365. [CrossRef]

3. Krechowicz, M.; Kiliańska, K. Interorganizational Relationships in Chosen Areas (Relacje Międzyorganizacyjne W Wybranych ObSzarach; Kielce Universtity of Technology: Kielce, Poland, 2019.

4. Silvius, G. Sustainability as a new school of thought in project management. J. Clean. Prod. 2017, 166, 1479-1493. [CrossRef]

5. Silvius, G.; Schipper, R. Sustainability in project management: A literature review and impact analysis. Soc. Bus. 2014, 4, 63-96. [CrossRef]

6. Silvius, G.; Marnewick, C. Interlinking Sustainability in Organizational Strategy, Project Portfolio Management and Project Management A Conceptual Framework. Procedia Comput. Sci. 2022, 196, 938-947. [CrossRef]

7. Molenaar, K.R.; Sobin, N.; Antillón, E.I. A Synthesis of Best-Value Procurement Practices for Sustainable Design-Build Projects in the Public Sector. J. Green Build. 2010, 5, 148-157. [CrossRef]

8. Sanchez, M. Integrating sustainability issues into project management. J. Clean. Prod. 2015, 96, 319-330. [CrossRef]

9. Silvius, G. Integrating sustainability into project trisk management. In Managing Project Risks for Competitive Advantage in Changing Business Environments; Bodea, S., Purnus, A., Huemann, M., Hajdu, M., Eds.; IGI Global: Hershey; PA, USA, 2016.

10. Mirhosseini, A.F.; Pitera, K.; Odeck, J.; Welde, M. Sustainable Project Management: Reducing the Risk of Cost Inaccuracy Using a PLS-SEM Approach. Sustainability 2022, 14, 960. [CrossRef]

11. Surco-Guillen, Y.C.; Romero, J.; Rodríguez-Rivero, R.; Ortiz-Marcos, I. Success Factors in Management of Development Projects. Sustainability 2022, 14, 780. [CrossRef]

12. Eskerod, P.; Huemann, M. Sustainable development and project stakeholder management: What standards say. Int. J. Manag. Proj. Bus. 2013, 6, 36-50. [CrossRef]

13. Hennig-Thurau, T.; Klee, A. The impact of customer satisfaction and relationship quality on customer retention: A critical reassessment and model development. Psychol. Mark. 1997, 14, 737-764. [CrossRef]

14. Ashnai, B.; Smirnova, M.; Kouchtch, S.; Yu, Q.; Barnes, B.R.; Naudé, P. Assessing relationship quality in four business-to-business markets. Mark. Intell. Plan. 2009, 27, 86-102. [CrossRef]

15. Roberts, K.; Varki, S.; Brodie, R. Measuring the quality of relationships in consumer services: An empirical study. Eur. J. Mark. 2003, 37, 169-196. [CrossRef]

16. Mohd Nawi, M.N.; Lee, A.; Azman, M.N.A.; Kamar, K. A.M. Fragmentation Issue in Malaysian Industrialised Building System (IBS) Projects Critical Success Factors for Improving Team Integration in IBS Construction Projects. J. Eng. Sci. Technol. 2014, 9, 97-106. 
17. Mohd Nawi, M.N.; Nifa, F.A.A.; Ahmed, V. A Review of Traditional Project Procurement Towards Integrated Practice. Am.Eurasian J. Sustain. Agric. 2014, 8, 65-70.

18. Sheehy, B. Defining CSR: Problems and Solutions. J. Bus. Ethics 2014, 131, 625-648. [CrossRef]

19. Carroll, A.B.; Shabana, K.M. The Business Case for Corporate Social Responsibility: A Review of Concepts, Research and Practice. Int. J. Manag. Rev. 2010, 12, 85-105. [CrossRef]

20. Park, C.; Mool, P.; Naa, J.H.; Lee, C.G. The Effects of Creating Shared Value on Corporate Performance. J. Distrib. Sci. 2014, 12, 29-35. [CrossRef]

21. O'Riordan, L.; Fairbrass, J. Managing CSR Stakeholder Engagement: A New Conceptual Framework. J. Bus. Ethics 2013, 125, 121-145. [CrossRef]

22. Kiliańska, K. The activity of socially responsible enterprises as a factor supporting the improvement of the quality of life of the society (Działalność społecznie odpowiedzialnych przedsiębiorstw jako czynnik wspierający poprawę jakości życia społec-zeństwa). Studia I Mater. Misc. Oeconomicae 2017, 3, 355-366.

23. Kang, H.-H.; Liu, S.-B. Corporate social responsibility and corporate performance: A quantile regression approach. Qual. Quant. 2013, 48, 3311-3325. [CrossRef]

24. Rodriguez-Gomez, S.; Arco-Castro, M.L.; Lopez-Perez, M.V.; Rodríguez-Ariza, L. Where Does CSR Come from and Where Does It Go? A Review of the State of the Art. Adm. Sci. 2020, 10, 60. [CrossRef]

25. Closon, C.; Leys, C.; Hellemans, C. Perceptions of corporate social responsibility, organizational commitment and job satisfaction. Manag. Res. J. Iberoam. Acad. Manag. 2015, 13, 31-54. [CrossRef]

26. Zou, P.X.W.; Couani, P. Managing risks in green building supply chain. Arch. Eng. Des. Manag. 2012, 8, 143-158. [CrossRef]

27. Close, R.; Loosemore, M. Breaking down the site hoardings: Attitudes and approaches to community consultation during construction. Constr. Manag. Econ. 2014, 32, 816-828. [CrossRef]

28. Jiang, W.; Wong, J.K. Key activity areas of corporate social responsibility (CSR) in the construction industry: A study of China. J. Clean. Prod. 2016, 113, 850-860. [CrossRef]

29. Lou, E.C.W.; Lee, A.; Mathison, G. Recapitulation of corporate social responsibility (CSR) for construction SMEs in the UK. In Proceedings of the 27th Annual ARCOM Conference 2011, Bristol, UK, 5-7 September 2011; Egbu, C., Lou, E.C.W., Eds.; Association of Researchers in Construction Management: Bristol, UK, 2011; pp. 673-682.

30. Zhao, Z.-Y.; Zhao, X.-J.; Davidson, K.; Zuo, J. A corporate social responsibility indicator system for construction enterprises. J. Clean. Prod. 2012, 29-30, 277-289. [CrossRef]

31. Bernaciak, A.; Halaburda, M.; Bernaciak, A. The Construction Industry as the Subject of Implementing Corporate Social Responsibility (the Case of Poland). Sustainability 2021, 13, 9728. [CrossRef]

32. Duman, D.U.; Giritli, H.; McDermott, P. Corporate social responsibility in construction industry: A comparative study between UK and Turkey. Built Environ. Proj. Asset Manag. 2016, 6, 218-231. [CrossRef]

33. Kowalczyk, R. How does stakeholder pressure influence CSR-practices? A construction industry model based on a European sample. In New Challenges in Economic Policy, Business, and Management; Ujwary-Gil, A., Gancarczyk, M., Eds.; Institute of Economics, Polish Academy of Sciences: Warsaw, Poland, 2020; pp. 319-333.

34. Paliwoda-Matiolińska, A. Odpowiedzialność Społeczna W Procesie Zarządzania Przedsiębiorstwem (Social Responsibility in the Enterprises Management Process); Wydawnictwo CH Beck: Warsaw, Poland, 2009.

35. Lehtinen, J.; Aaltonen, K. Organizing external stakeholder engagement in inter-organizational projects: Opening the black box. Int. J. Proj. Manag. 2020, 38, 85-98. [CrossRef]

36. McCarthy, S.; O’Raghallaigh, P.; Fitzgerald, C.; Adam, F. Shared and fragmented understandings in interorganizational IT project teams: An interpretive case study. Int. J. Proj. Manag. 2021, 39, 762-773. [CrossRef]

37. Yong, C.Y.; Mustaffa, N.E. Analysis of factors critical to construction project success in Malaysia. Eng. Constr. Archit. Manag. 2012, 19, 543-556. [CrossRef]

38. Oliveira, G.S.; Rabechini, J., Jr. Stakeholder management influence on trust in a project: A quantitative study. Int. J. Proj. Manag. 2019, 37, 131-144. [CrossRef]

39. Simard, M.; Aubry, M.; Laberge, D. The utopia of order versus chaos: A conceptual framework for governance, organizational design and governmentality in projects. Int. J. Proj. Manag. 2018, 36, 460-473. [CrossRef]

40. Jelodar, M.B.; Yiu, T.W.; Wilkinson, S. A conceptualisation of relationship quality in construction procurement. Int. J. Proj. Manag. 2016, 34, 997-1011. [CrossRef]

41. Berlin, J.M.; Carlström, E.D. Why is collaboration minimised at the accident scene? A critical study of a hidden phenomenon. Disaster Prev. Manag. 2011, 20, 159-171. [CrossRef]

42. Khouja, A.; Lehoux, N.; Cimon, Y.; Cloutier, C. Collaborative Interorganizational Relationships in a Project-Based Industry. Buildings 2021, 11, 502. [CrossRef]

43. Savolainen, J.M.; Saari, A.; Männistö, A.; Kähkonen, K. Indicators of collaborative design management in construction projects. J. Eng. Des. Technol. 2018, 16, 674-691. [CrossRef]

44. Davis, P.; Love, P. Alliance contracting: Adding value through relationship development. Eng. Constr. Arch. Manag. 2011, 18, 444-461. [CrossRef]

45. Sundquist, V.; Hulthén, K.; Gadde, L.E. From project partnering towards strategic supplier partnering. Eng. Constr. Arch. Manag. 2018, 25, 358-373. [CrossRef] 
46. Jelodar, M.B.; Yiu, T.W.; Wilkinson, S. Assessing Contractual Relationship Quality: Study of Judgment Trends among Construction Industry Participants. J. Manag. Eng. 2017, 33, 4016028. [CrossRef]

47. Toppinen, A.; Miilumäki, N.; Vihemäki, H.; Toivonen, R.; Lähtinen, K. Collaboration and Shared Logic for Creating Val-ue-Added in Three Finnish Wooden Multi-Storey Building Projects. Wood Mater. Sci. Eng. 2019, 14, 269-279. [CrossRef]

48. Walker, D.H.T.; Johannes, D.S. Construction Industry Joint Venture Behaviour in Hong Kong-Designed for Collaborative Results? Int. J. Proj. Manag. 2003, 21, 39-49. [CrossRef]

49. Hu, Y.; Chan, A.P.C.; Le, Y. Understanding the Determinants of Program Organization for Construction Megaproject Suc-cess: Case Study of the Shanghai Expo Construction. J. Manag. Eng. 2015, 31, 5014019. [CrossRef]

50. Eriksson, P.E.; Atkin, B.; Nilsson, T. Overcoming barriers to partnering through cooperative procurement procedures. Eng. Constr. Arch. Manag. 2009, 16, 598-611. [CrossRef]

51. Sparkling, A.E.; Mollaoglu, S.; Kirca, A. Research Synthesis Connecting Trends in Architecture, Engineering, and Construction Project Partnering. J. Manag. Eng. 2017, 33, 4016033. [CrossRef]

52. Segerstedt, A.; Olofsson, T. Supply chains in the construction industry. Supply Chain Manag. Int. J. 2010, 15, 347-353. [CrossRef]

53. Davey, C.L.; Lowe, D.J.; Duff, A.R. Generating Opportunities for SMEs to Develop Partnerships and Improve Performance. Build. Res. Inf. 2001, 29, 1-11. [CrossRef]

54. Hulstijn, J.; Gordijn, J. Risk analysis for inter-organizational controls. ICEIS 2010, 3, 314-320. [CrossRef]

55. Kubba, S. Types of Building Contract Agreements. In Handbook of Green Building Design and Construction: LEED, BREEAM, and Green Globes, 2nd ed.; Butterworth-Heinemann: Cambridge, UK, 2017.

56. Konchar, M.; Sanvido, V. Comparison of U.S. Project Delivery Systems. J. Constr. Eng. Manag. ASCE 1998, 124, 435-444. [CrossRef]

57. Sedita, S.R.; Apa, R. The impact of inter-organizational relationships on contractors' success in winning public procurement projects: The case of the construction industry in the Veneto region. Int. J. Proj. Manag. 2015, 33, 1548-1562. [CrossRef]

58. Griffiths, F. Alliance Partnership Sourcing-A Major Tool for Strategic Procurement; Frank Grifftths Associates Limited: Kib-worth Beauchamp, UK, 1992.

59. Watson, K. No hiding place. Constr. Manag. 1994, 2, 12-14.

60. Black, C.; Akintoye, A.; Fitzgerald, E. An analysis of success factors and benefits of partnering in construction. Int. J. Proj. Manag. 2000, 18, 423-434. [CrossRef]

61. Fellows, R. The Culture of Partnering Procurement-A Key to Innovation. In Proceedings of the CIB Proceeding 1977, Edingburgh, UK, 1 September 1977; pp. 193-202.

62. Walker, D.H.; Hampson, K. Enterprise networks. In Partnering and Alliancing; Blackwell Science Ltd.: London, UK, 2003.

63. MacNeil, I.R. Contracts: Adjustment of long-term economic relations under classical, neoclassical and relation contract law. Northwestern Univ. Law Rev. 1978, 72, 854.

64. Meng, X.; Sun, M.; Jones, M. Maturity Model for Supply Chain Relationships in Construction. J. Manag. Eng. 2011, 27, 97-105. [CrossRef]

65. Krechowicz, M. Effective Risk Management in Innovative Projects: A Case Study of the Construction of Energy-efficient, Sustainable Building of the Laboratory of Intelligent Building in Cracow. IOP Conf. Ser. Mater. Sci. Eng. 2017, $245,62006$. [CrossRef]

66. Krechowicz, M. Risk Management in Complex Construction Projects that Apply Renewable Energy Sources: A Case Study of the Realization Phase of the Energis Educational and Research Intelligent Building. IOP Conf. Ser. Mater. Sci. Eng. 2017, $245,62007$. [CrossRef]

67. Gierczak, M.K. The hybrid Fuzzy Fault and Event Tree analysis in the geotechnical risk management in HDD projects. Georisk: Assess. Manag. Risk Eng. Syst. Geohazards 2020, 15, 12-26. [CrossRef]

68. Krechowicz, M.; Kiliańska, K. Risk and Opportunity Assessment Model for CSR Initiatives in the Face of Coronavirus. Sustainability 2021, 13, 6177. [CrossRef]

69. Carlsson, M.; Hintze, S.; Stille, H. On risk management in large infrastructure projects. In Proceedings of the 16th International Conference on Soil Mechanics and Geotechnical Engineering, Osaka, Japan, 12-16 September 2000; Millpress: Rotterdam, the Netherlands; pp. 2785-2788.

70. Pritchard, C. Risk Management in Projects: Concepts and Guidance (Zarzadzanie Ryzykiem W Projektach: Teoria I Praktyka); WIG-PRESS: Warszawa, Poland, 2002.

71. Nuchpho, P.; Nansaarng, S.; Pongpullponsak, A. Risk Assessment in the Organization by using FMEA Innovation: A Literature Review. In Proceedings of the 7th International Conference on Educational Reform (ICER 2014), Innovations and Good Practices in Education, Seville, Spain, 17-19 November 2014; pp. 781-789.

72. Krechowicz, M.; Gierulski, W.; Loneragan, S.; Kruse, H. Human and equipment risk factors evaluation in Horizontal Directional Drilling technology using Failure Mode and Effect Analysis. Manag. Prod. Eng. Rev. 2021, 12, 45-56. [CrossRef]

73. Knights, P.F. Rethinking Pareto analysis: Maintenance applications of logarithmic scatterplots. J. Qual. Maint. Eng. 2001, 7 , 252-263. [CrossRef]

74. Bociaga, M.; Klimecka-Tatar, D. Quality management tools in the cement industry, Engineering Knowledge Archive 2016. Narzędzia Zarzadzania Jakościa W Branży Cementowej. Arch. Wiedzy Inżynierskiej 2016, 1, 36-38.

75. Roszak, M. Quality management in engineering practice (Zarządzanie jakością w praktyce inżynierskiej). Sci. Int. J. World Acad. Mater. Manuf. Eng. 2014, 1, 51-68. 
76. Cox, A.; Thompson, I. 'Fit for purpose' contractual relations: Determining a theoretical framework for construction projects. Eur. J. Purch. Supply Manag. 1997, 3, 127-135. [CrossRef]

77. Rahman, M.M.; Kumaraswamy, M.M. Potential for Implementing Relational Contracting and Joint Risk Management. J. Manag. Eng. 2004, 20, 178-189. [CrossRef]

78. Meng, X. Assessment framework for construction supply chain relationships: Development and evaluation. Int. J. Proj. Manag. 2010, 28, 695-707. [CrossRef]

79. Kesidou, S.; Sovacool, B.K. Supply chain integration for low-carbon buildings: A critical interdisciplinary review. Renew. Sustain. Energy Rev. 2019, 113, 109274. [CrossRef]

80. Turner, J.R.; Müller, R. Choosing Appropriate Project Managers: Matching Their Leadership Style to the Type of Project; Project Management Institute: Newtown Square, PA, USA, 2006.

81. Mesa, H.A.; Molenaar, K.R.; Alarcón, L.F. Exploring performance of the integrated project delivery process on complex building projects. Int. J. Proj. Manag. 2016, 34, 1089-1101. [CrossRef]

82. Singleton, T.; Cormican, K. The Influence of Technology on the Development of Partnership Relationships in the Irish Construction Industry. Int. J. Comput. Integr. Manuf. 2013, 26, 19-28. [CrossRef]

83. Beach, R.; Webster, M.; Campbell, K.M. An Evaluation of Partnership Development in the Construction Industry. Int. J. Proj. Manag. 2005, 23, 611-621. [CrossRef]

84. Li, H.; Cheng, E.W.; Love, P.E. Partnering research in construction. Eng. Constr. Arch. Manag. 2000, 7, 76-92. [CrossRef]

85. Krechowicz, M. Comprehensive Risk Management in Horizontal Directional Drilling Projects. J. Constr. Eng. Manag. 2020, 146, 4020034. [CrossRef]

86. Krechowicz, M.; Krechowicz, A. Risk Assessment in Energy Infrastructure Installations by Horizontal Directional Drilling Using Machine Learning. Energies 2021, 14, 289. [CrossRef] 